Mouse Chase: Detecting Careless and Unmotivated Responders Using Cursor Movements in Web-Based Surveys

Artur Pokropek ${ }^{1}$

Tomasz Żółtak ${ }^{1}$

Marek Muszyński ${ }^{1}$

${ }^{1}$ Institute of Philosophy and Sociology, Polish Academy of Sciences

Author Note

Correspondence concerning this article should be sent to Prof. Artur Pokropek, Institute of Philosophy and Sociology, Polish Academy of Sciences, ul. Nowy Świat 72, 00-330 Warszawa, Poland. E-mail: artur.pokropek@gmail.com.

This research is financed by the National Science Centre $(\mathrm{NCN})$ research grant (2019/33/B/HS6/00937) Understanding response styles in self-report data: consequences, remedies and sources.

The article was published on March $21^{\text {st }}$ in European Journal of Psychological Assessment. Please cite as: Pokropek, A., Żółtak, T., and Muszyński, M. (2023). Mouse Chase: Detecting Careless and Unmotivated Responders Using Cursor Movements in Web-Based Surveys, European Journal of Psychological Assessment, Doi:https://doi.org/10.1027/1015$5759 / \mathrm{a} 000758$ (the version in the journal is to be treated as final and referential) 


\begin{abstract}
Web surveys offer new research possibilities, but they also have specific problems. One of them is a higher risk of careless, inattentive, or otherwise invalid responses. Using paradata, which are data collected apart from reactionary data, is one of the potential tools that can help to screen for problematic responses in web-based surveys. One of the most promising forms of paradata is the movement, or trajectory, of the cursor in making a response. This study constructed indicators of such data, presented correlations between them and provided an interpretation and validation of these components by correlating them with previously known indices of careless responding. Finally it tested cursor movement indices during different motivational states induced by experimental instructions. Cursor movement indices proved to be moderately related to classical careless responding indices but some of them (horizontal distance traveled as well speed and acceleration on vertical dimension) were as responsive to manipulation conditions as classical indices. Potential role of cursor movement indices in survey practice and future studies in this area are discussed.
\end{abstract}

Keywords: paradata, web survey, survey methodology, cursor movement, careless/insufficient effort responding (C/IER). 


\section{Mouse Chase: Detecting Careless and Unmotivated Responders Using Cursor Movements in Web-Based Surveys}

The introduction of web-based surveys has been a major development in social sciences methodology, and it has facilitated and enriched data collection in many respects. Web-based surveys are not without their problems, though; in this article, we will address one of them: careless or insufficient effort responding (C/IER; Johnson, 2005).

The absence of interviewers during a survey is likely to lower participant motivation and interest making web-based environments especially vulnerable to C/IER (Johnson, 2005; Meade \& Craig, 2012), and other forms of distraction such as background noise, technical problems, or multitasking activities (Zwarun \& Hall, 2014). Data provided by unmotivated, careless, or inattentive respondents can lead to serious distortions in measurement (Johnson, 2005; Meade \& Craig, 2012). Recent C/IER detection approaches rely on (1) special items designed to detect careless responses (Huang et al., 2012; Meade \& Craig, 2012), (2) response consistency indices formed from responses to typical survey items (Huang et al., 2012), (3) multivariate outlier analysis (Meade \& Craig, 2012), (4) response time analysis (Ulitzsch et al., 2022), and (5) selfreported scales of diligence (Meade \& Craig, 2012). None of these methods guarantee a flawless identification of careless responses. The main recommendation is to use a combination of these methods to better predict C/IER (Curran, 2016; Meade \& Craig, 2012).

The aim of this article is to provide and examine an additional set of indicators that could predict C/IER, that is, cursor movement indices (CMIs). Cursor tracking is a relatively recently developed behavioral methodology that offers potentially promising indicators of the cognitive processes underlying survey responses. There is strong theoretical and empirical evidence that people's cognitive, attitudinal, and affective states are expressed in their bodily actions 
(Yamauchi \& Xiao, 2018). On those grounds, data on cursor movements have been extensively used in web design studies (Huang et al., 2011; Rodden et al., 2008) and controlled laboratory experiments to test social cognition models (Kieslich \& Henninger, 2017; Stillman et al., 2018), but were relatively less explored in the context of web-based surveys. In the latter, mouse movements were successfully used to predict respondent confusion and difficulty in answering questions (Fernández-Fontelo et al., 2022; Horwitz et al., 2017, 2020; Steiger \& Reips, 2010).

In a web-based study Steiger and Reips (2010) have manually coded movement data and looked for indicators of lower criterion-related validity, pointing towards long idleness periods and excessive mouse movements as indicators of confusion and lower data quality. Horwitz et al. (2020) and Fernadez-Fontelo et al. (2022) used another web survey experiment to verify whether cursor moves have potential to capture participants' difficulties due to experimentally induced item difficulty (e.g. unordered response categories). They have found that some of the moves (e.g. regressions between important areas of survey page or holding cursor above key page areas) are predictive of respondent difficulties over and above response times.

To the best of our knowledge, however, cursor-based indices have not been investigated for the detection of C/IER. We have thus decided to link CMIs usage with rich C/IER literature and explore their utility in measuring careless responding. Unlike some of the previous studies (Horwitz et al., 2017; Steiger \& Reips, 2010) our study employs a fully automated collection and processing of process data, also analyzing different indicators that were studied by our predecessors (Horwitz et al., 2020; Steiger \& Reips, 2010). We also test CMIs under different motivational conditions that were experimentally manipulated. Moreover, our data come from the largest to date sample in CMIs studies (> 2000) and employs questions and scales most frequently used in (psycho)educational assessment and public opinion research, in contrast to 
previous studies that have mostly used factual questions and yes/no items, i.e. items more seldom used in practice (Horwitz et al., 2017; Steiger \& Reips, 2010). In this way, we want to broaden the arsenal of researchers against C/IER by exploring possibilities that CMIs offer in this regard.

To this end we developed a set of CMIs that combined timing and trajectory data and collated and compared them with five C/IER detection indices (Meade \& Craig, 2012). First, we analyzed correlations between different CMIs. Second, we predicted that CMIs were significantly correlated with classic C/IER indicators. Third, we hypothesized that CMIs would significantly differ between experimental conditions that targeted participants' motivation, as had previously been shown for some of the classic C/IER indices (Burns et al., 2015; Huang et al., 2012). In this way, we aimed to establish process indicators for C/IER based on both survey responses and paradata. Paradata are understood here as by-products - data collected additionally to actual survey responses (substantive data) of which process data (and indicators derived from it) are a special case conveying extra information specifically about survey responding and navigating (Kroehne \& Goldhamer, 2018).

\section{Data and Methods}

\section{Participants}

Data were collected between 23rd November and 6th December 2021 in web-based mode, using opt-in Internet panel Ariadna. Respondents participated in the study using their own computers (either desktop or laptop) and we had no control over the environment in which they completed the questionnaire. Respondents were remunerated for the completed interview with points that could be exchanged into small gifts. The experiment was begun by 3407 respondents, but, mostly for technical reasons, only 2023 were retained in the analysis (see Supplementary Online Materials for details). Characteristics of the final sample are presented in Table 1. 
Table 1 Participant Characteristics

\begin{tabular}{llrr}
\hline Characteristic & Value & N & Percentage \\
\hline Gender & Male & 941 & $46.5 \%$ \\
& Female & 1082 & $53.5 \%$ \\
\hline Age & $18-29$ & 481 & $23.8 \%$ \\
& $30-39$ & 693 & $34.3 \%$ \\
& $40-50$ & 849 & $42.0 \%$ \\
\hline \multirow{2}{*}{ Education } & Secondary & 1067 & $52.7 \%$ \\
& Tertiary & 956 & $47.3 \%$ \\
\cline { 2 - 4 } & Total & 2023 & $100.0 \%$ \\
\hline
\end{tabular}

\section{Procedure}

At the beginning of the survey, respondents were randomly assigned to one of three sets of test instructions (provided in the form of a short video): (1) standard, containing an invitation to the survey and brief information on its contents, (2) warning, containing a caution against responding carelessly to the survey and a reminder that participants responding carelessly could be excluded from the survey, thus losing their remuneration, and (3) appeal, containing a detailed description of the questionnaire, as well as a request to participants to respond diligently due to the social importance of the survey. The types of instruction were modeled after the literature (Adair, 2014; Burns et al., 2015; Huang et al., 2012). Respondents were also randomly assigned to one of several experimental conditions in which the number and format of response categories was manipulated (from a 4-point to an 11-point scale). This was independent of the assignment to the set of test instructions. The approval of the institutional ethical committee was sought and obtained.

The study included several parts, starting with a Polish adaptation of cognitive abilities test Pathfinder (Malanchini et al., 2021), followed by several survey scales, manipulation check and self-reported survey diligence scale. In the main analysis we focused on one scale and the second 
scale is used for cross-validation (Tables S12-17). The order of measurement and manipulations used in the study is displayed in Table S1. All participants responded to the measures in the same order.

\section{Materials}

The analysis covered survey responses and paradata collected from a reading attitudes scale of 11 items, including 5 reversed, that was originally used to construct a unidimensional scale in PISA 2000, 2009, and 2018. In this experiment, the version from PISA 2009 was used as it was the longest (OECD, 2010). The whole scale was displayed on one screen - it was the 8th screen in the survey part.

\section{C/IER Indices}

We decided to use five of the classic C/IER indices: (1) control questions (QC) failure, (2) longstring index, (3) Mahalanobis distance, (4) page time, and (5) self-reported diligence. In this way, we covered the main approaches to C/IER indices, that is, the response pattern, response inconsistency, and response time analysis (Huang et al., 2012; Meade \& Craig, 2012).

Control questions were taken from Pathfinder: they were just four very easy items, correct solving of which should be evident for all participants. Number of incorrect responses to these questions served as an indicator (Malanchini et al., 2021). The Mahalanobis distance returns a value indicating the distance from the data center in a multivariate normal distribution. This measure serves for finding outlier, aberrant participants in the dataset. The longstring measure is the number of identical responses in a row (i.e., longest uninterrupted string of identical responses). The page time is used on the basis of an assumption that very short responses indicate insufficient cognitive processing. According to common practice, we used the natural logarithm of page time to account for skewness of this measure. Self-reported measures of 
survey effort tend to converge with other C/IER indices and can also be used as a self-standing

C/IER indicator. The items used in this experiment were adapted from the scale presented by Meade and Craig (2012; see Table S5).

\section{Cursor Movement Indicators}

We constructed four sets of indicators based on cursor movement: (1) total distance traveled, (2) average speed, (3) average absolute acceleration of cursor move, and (4) number of flips, that is, changes of direction of movement (cf. Horwitz et al., 2017; Steiger \& Reips, 2010).

Because the layout of the page could vary between respondents due to the size of their windows, browser type, or other factors, we constructed relative indicators of the traveled distance in the horizontal $\left(d X \_r e l\right)$ and vertical $\left(d Y \_r e l\right)$ dimensions. They were computed by dividing total horizontal or vertical distance (in pixels) traveled by the response table size (distance between the position of the first answer to the first item and position of the last answer to the last item).

Prior research showed that the position of the cursor was relatively close to the position of the eye gaze on the screen (Clark \& Stephane, 2018; Kirsh \& Joy, 2020) therefore, we stipulated that the distance traveled reflected the survey response-related behaviors. A short distance traveled should therefore indicate less reading, less hesitation, and a smaller number of opinion changes or adjustments to the response categories, and, therefore, it could be related to more C/IER. The shortest possible distance traveled indicated a straight line, and, therefore, it seemed natural that the horizontal distance traveled should be a good measure of straightlining. The vertical dimension should also be of some importance, because a long distance traveled in it may indicate going back to items and changing the responses, or thinking of changing them, thus indicating more careful responding (Horwitz et al., 2017; 2020). There was also evidence that an 
excessive distance traveled could indicate confusion and difficulty in making a response (Stieger \& Reips, 2010).

Another two indices reported the average speed of the cursor moves in horizontal $(v X)$ and vertical $(v Y)$ directions (in pixels per second $[\mathrm{px} / \mathrm{s}]$ ). Following the theory that the cursor is relatively close to the position of the eye gaze on the screen, a high speed in both dimensions should indicate inattentiveness or speeding. The vertical speed could be a good indicator of straightlining, as we expected that it was related to rapid response patterns that follow a straight line.

The third set of indices reported the average absolute acceleration of cursor moves in the horizontal direction $(a X)$ and vertical direction $(a Y)$ (in pixels per squared second $\left[\mathrm{px} / \mathrm{s}^{2}\right]$ ). According to previous data, high average absolute acceleration could indicate distractions (Brenner \& Smeets, 2003).

Finally, we counted the number of flips, that is, changes in direction of movements, again separately for horizontal (flipsX) and vertical (flipsY) directions. We assumed that respondents used direction changes to reach thought-over responses and that straightlining should be indicated by a small number of flips. A very large number of flips could also indicate hesitancy or indecisiveness (Horwitz et al., 2020; Steiger \& Reips, 2010).

\section{Analysis}

Pearson correlation coefficients were used to explore relations between cursor moves and C/IER indicators. Analysis of variance (ANOVA) was conducted in the 3 (experimental instructions: standard, warning, appeal) x 8 (scale length: 4, 5, 6, 7, 10, or 11 all-labeled response categories plus 10 or 11 end-labeled response categories) between-participants design to compare the cursor moves and C/IER indices between the experimental conditions. We reported 
post-hoc differences only for the main effects for instruction conditions, treating the length of the scale as a controlled confounding factor. Also, we checked for statistical significance of the interaction effects to assess homogeneity of effect of instruction type across different response scale lengths and formats.

We have transformed CMIs using either square root (flips) or natural logarithm (other indices) to account for non-normal distributions of the variables.

\section{Results}

Relationships between cursor movement and C/IER indices, depicted in Table 3, are at best moderate and as such comparable to the strength of the relationships between different C/IER indices (cf. Tables S8 and S9 and see Huang et al., 2012; Meade \& Craig, 201210). Clearly, the two CMIs most strongly correlated with the C/IER indices are the horizontal distance traveled and the number of vertical flips. On the other hand, the C/IER measures correlated most strongly with at least some CMIs are the page time, longstring index, and self-reported diligence.

Table 2 Pearson correlations between cursor moves and CIE/R indices

\begin{tabular}{|c|c|c|c|c|c|}
\hline Measure & Longstring & Mahalanobis & $\begin{array}{l}\text { Pathfinder QC } \\
\text { Failures }\end{array}$ & $\begin{array}{l}\text { Self-Reported } \\
\text { Diligence }\end{array}$ & log(Page Time $)$ \\
\hline $\log (\mathrm{dX}$ _rel $)$ & $-0.70 * * *$ & $0.12 * * *$ & $-0.26 * * *$ & $0.47 * * *$ & $0.59 * * *$ \\
\hline $\log (\mathrm{dY}$ _rel $)$ & $-0.18 * * *$ & $0.07 * *$ & -0.04 & $0.13 * * *$ & $0.40 * * *$ \\
\hline sqrt(flipsX) & $-0.32 * * *$ & $0.07 * *$ & $-0.14 * * *$ & $0.20 * * *$ & $0.49 * * *$ \\
\hline sqrt(flipsY) & $-0.44 * * *$ & $0.08 * * *$ & $-0.15 * * *$ & $0.28 * * *$ & $0.55^{* * *}$ \\
\hline $\log (\mathrm{vX})$ & $-0.39 * * *$ & $0.07 * *$ & $-0.14 * * *$ & $0.25^{* * *}$ & $-0.22 * * *$ \\
\hline $\log (\mathrm{vY})$ & $0.38^{* * *}$ & $-0.09 * * *$ & $0.17 * * *$ & $-0.27 * * *$ & $-0.75 * * *$ \\
\hline $\log (a X)$ & $-0.28 * * *$ & -0.02 & $-0.12 * * *$ & $0.19 * * *$ & $-0.18 * * *$ \\
\hline $\log (a Y)$ & $0.23 * * *$ & $-0.14 * * *$ & $0.09 * * *$ & $-0.17 * * *$ & $-0.54 * * *$ \\
\hline
\end{tabular}

$\mathrm{N}=2007$ for correlation involving self-reported diligence.

$\mathrm{N}=2023$ for all the other correlations.

$* * * p<.001 ; * * p<.01, * p<.05$.

The horizontal distance traveled was strongly negatively correlated with the longstring 
index. It also correlated moderately negatively with QC failures, and positively with the selfreported diligence and page time. In contrast, the vertical distance was moderately correlated with the page time and correlated to a much lesser degree with the longstring index and self-reported diligence. Flips in both dimensions correlated mostly with the longstring index (negatively) and page time (positively). Their correlations with self-reported diligence and QC failures were considerably weaker. The speed and acceleration of cursor moves had a similar pattern of relationships with all the $\mathrm{CIE} / \mathrm{R}$ indexes except for page time. They correlated moderately with the longstring index and slightly weaker with self-reported diligence and QC failures - in each case negatively with regards to horizontal measures and positively with regards to vertical ones. On the other hand, correlations with page time were all negative and while they were strong for vertical measures, for horizontal ones they were much weaker.

Regarding the experimental manipulations, in both the warning and appeal conditions, participants traveled a longer horizontal distance and did it with lower speed in comparison with the standard instruction condition. Similarly, participants yielded higher scores of self-reported involvement, lower scores of the longstring index, and longer page time in the warning and appeal conditions in comparison with the standard condition. Also, they made more vertical flips and had lower absolute acceleration, but the first of these effects was statistically significant only for the appeal condition, and the latter only for the warning condition. The size of the effects was rather small and did not differ considerably between the warning and appeal conditions. The remaining indices did not differ significantly between the experimental conditions (cf. Figure 1 and Tables S10 and S11).

Most measures showed no interaction between instruction type and response scale length with the exception of vertical distance and QC failures (Table S11). 
Table 4 Results of ANOVAs

\begin{tabular}{|c|c|c|c|c|c|c|c|c|c|}
\hline \multirow[b]{2}{*}{ Measure } & \multicolumn{3}{|c|}{ Instruction main effect } & \multicolumn{3}{|c|}{ Response scale main effect } & \multicolumn{3}{|c|}{$\begin{array}{l}\text { Interaction: instruction } \mathrm{X} \\
\text { response scale }\end{array}$} \\
\hline & $F$ & $p$ & partial $\eta^{2}$ & $F$ & $p$ & partial $\eta^{2}$ & $F$ & $p$ & partial $\eta^{2}$ \\
\hline $\log (\mathrm{dX}$ _rel $)$ & 5.71 & 0.003 & 0.006 & 1.85 & 0.074 & 0.006 & 1.38 & 0.153 & 0.010 \\
\hline $\log \left(\mathrm{dY} \mathrm{C}_{\mathrm{rel}}\right)$ & 1.95 & 0.142 & 0.002 & 8.24 & 0.000 & 0.028 & 1.80 & 0.033 & 0.012 \\
\hline sqrt(flipsX) & 1.68 & 0.186 & 0.002 & 2.06 & 0.045 & 0.007 & 1.22 & 0.251 & 0.008 \\
\hline sqrt(flipsY) & 3.12 & 0.045 & 0.003 & 2.23 & 0.029 & 0.008 & 1.39 & 0.150 & 0.010 \\
\hline $\log (\mathrm{aX})$ & 0.93 & 0.397 & 0.001 & 1.47 & 0.172 & 0.005 & 0.93 & 0.530 & 0.006 \\
\hline $\log (\mathrm{aY})$ & 6.19 & 0.002 & 0.006 & 2.04 & 0.047 & 0.007 & 0.43 & 0.966 & 0.003 \\
\hline $\log (\mathrm{v} X)$ & 0.06 & 0.941 & 0.000 & 1.72 & 0.100 & 0.006 & 1.19 & 0.276 & 0.008 \\
\hline $\log (\mathrm{vY})$ & 9.47 & 0.000 & 0.009 & 1.04 & 0.398 & 0.004 & 0.92 & 0.538 & 0.006 \\
\hline $\begin{array}{l}\text { Self-reported } \\
\text { diligence }\end{array}$ & 32.40 & 0.000 & 0.031 & 1.43 & 0.188 & 0.005 & 1.40 & 0.144 & 0.010 \\
\hline Longstring & 5.20 & 0.006 & 0.005 & 1.07 & 0.381 & 0.004 & 1.53 & 0.094 & 0.011 \\
\hline $\log ($ Page time $)$ & 8.67 & 0.000 & 0.009 & 3.61 & 0.001 & 0.012 & 1.24 & 0.238 & 0.009 \\
\hline $\begin{array}{l}\text { Pathfinder QC } \\
\text { failures }\end{array}$ & 0.97 & 0.378 & 0.001 & 1.12 & 0.350 & 0.004 & 2.28 & 0.004 & 0.016 \\
\hline Mahalanobis & 0.60 & 0.546 & 0.001 & 174.42 & 0.000 & 0.378 & 1.66 & 0.057 & 0.012 \\
\hline
\end{tabular}

$\mathrm{N}=2007$ for analysis involving self-reported diligence as a dependent variable.

$\mathrm{N}=2023$ for all the other analyses.

Note: Test statistics and partial $\eta^{2}$ for main effects computed in the absence of the interaction effect (type II test). 


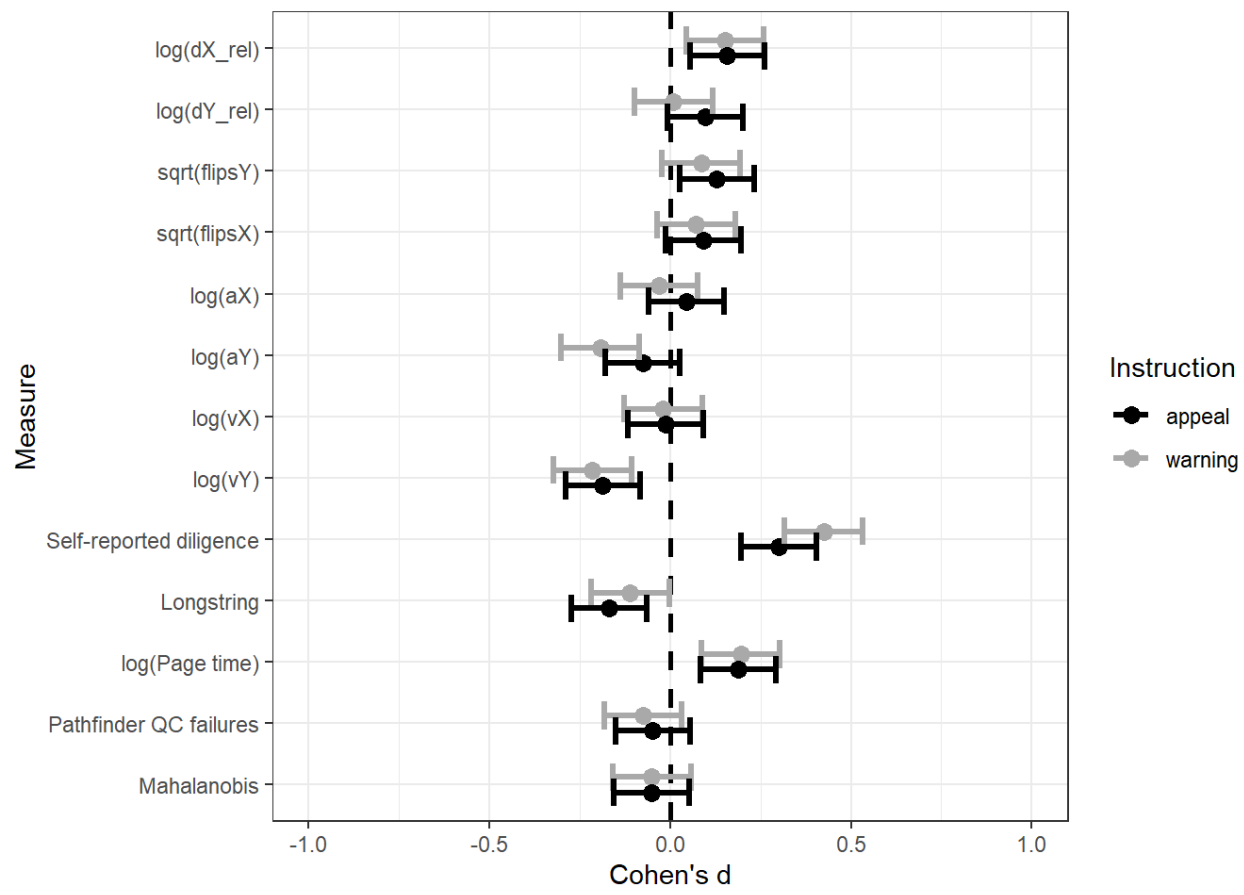

Figure 1. Effect size of warning and appeal instructions (compared with the standard instruction) for different measures, along with the $95 \%$ confidence intervals.

\section{Discussion}

The emerging literature suggests that cursor movements could be used to predict the cognitive states of survey respondents (Fernández-Fontelo et al., 2022; Horwitz et al., 2020; Yamauchi \& Xiao, 2018). This paper was devoted to exploring the possibilities of using cursor movements to construct indicators that would help to identify careless or insufficient effort responding (C/IER). This is a crucial issue in an era dominated by web-based research where the physical disconnection of the researcher and respondent is likely to lower motivation and participant interest in the survey significantly, reducing the quality of the measurement (Johnson, 2005).

\section{Conclusions}

The general conclusion is that CMIs are a promising source of information about 
respondents' involvement in a survey and might be used as additional information for existing C/IER indicators. First, the results of our analyses indicated that CMIs are significantly correlated with classic C/IER indicators and that the direction of correlations meets both the theoretical and common-sense patterns. Measures of distance traveled and the number of flips were negatively related to the longstring index, positively to the self-reported diligence and page time, and very weakly to the Mahalanobis distance. Indicators of speed and acceleration showed positive relations with C/IER in case of vertical indices and negative in case of horizontal ones.

Second, we hypothesized that the CMIs would significantly differ between experimental conditions. Here we found only weak effects. Consistently significant effects occurred for the horizontal distance traveled, which was larger in conditions inducing higher motivation and for the vertical speed, which was smaller in such conditions. Also, the number of vertical flips and absolute acceleration differed, but only in either appeal or warning conditions. The effects for the C/IER indices were also small, except for the longstring index, page time, and self-reported diligence. The effect size (Cohen's $d$ ) of the longstring index ( 0.15 for warning, 0.16 for appeal instruction) and page time ( 0.20 and 0.19 , respectively) was similar to that of the cursor distance traveled $(0.15$ and 0.16$)$ and speed on vertical dimension $(-0.21,-0.19)$. Only the self-reported diligence showed substantially higher effects (0.41 and 0.30$)$.

The results suggest that CMIs provide us with additional tools to identify careless responding in survey data, potentially over and above classical C/IER indices and response times (Horwitz et al., 2017; 2020). Moreover, collecting CMIs has virtually no cost, is highly automated and noninvasive. It does not increase the duration of the interview nor does it bring problems related to reversed, attention check or bogus items (Huang et al., 2012; Meade \& Craig, 2012). 


\section{Limitations}

The study was not initially designed for mouse movement analysis. We did not record the information on different types of cursor devices used by our participants (e.g., touchpad vs. an actual mouse). However, we estimate that a vast majority $(\sim 81 \%)$ of users of the Ariadna panel

use a mouse ${ }^{1}$. Different types of devices might lead to noise in the constructed indicators. There is no detailed research on these issues, but some of the studies are suggesting that including or excluding touchpad users does not change the results significantly (Gatti et al., 2021). Moreover, we did not perform any advanced outlier analysis; however, in this state of knowledge it is very difficult to say how such an analysis should look like (cf. Horwitz et al., 2020). Moreover, our study was conducted in ecologically valid, but methodologically imperfect web mode. In this way, our results come from a setting typical for most modern-day surveys, but it also means that our process data come from an uncontrolled environment with a number of insufficiently researched factors that could lower the quality of the process data collected.

Another limitation of our study is that we present results from only one scale. To make up for that we have presented the same analyses on a different scale as a cross-validation of the above results (Tables S12-S17). The additional results point to virtually the same conclusions, giving a proof for robustness of our findings.

\section{Directions for Future Studies}

Future studies should strive to identify further links between CMIs and classic C/IER indices, providing mutual validation and enhancing knowledge about C/IER in web surveys in general. Further research should also compare cursor trajectories in participants flagged as careless with those yielding engaged responses. Validity studies, showing increase of survey data construct or criterion-related validity after accounting for C/IER flagged by CMIs are also needed. 
It also seems promising to compare cursor moves under different experimental manipulations, for example, under a cognitive load or fatigue, thus broadening our understanding and interpretation of this type of paradata. Cursor trajectories and related indices can also be used in faking and socially desirable responding research, for instance, as potential additional indices of faked or tailored response profiles.

Knowledge about sociodemographic, personality, and cognitive correlates of CMIs is still lacking. Future studies should offer insight in these areas, possibly in combination with mixture models, providing information on typical profiles of cursor moves. Importance of scale and item characteristics for CMIs, such as content and presence of negatively worded items, should also be systematically studied in future research.

Further still, not much is known on how CMIs differ on different devices (e.g., touchpad vs. mouse), with touch screens being terra incognita almost completely. The latter is especially important because completing web surveys on touch-screen devices (e.g., smartphones) is on the rise (Horwitz et al., 2017).

As CMIs research in survey context is still in its infancy there is a paramount need of methodological studies that would enable to set methodological standards, including hardware and software details, important for creating theoretically meaningful response processes indicators (Kroehne \& Goldhammer, 2018). To this end more empirical studies on CMIs are needed, including those relating process data with other information, e.g. eye-tracking, cognitive interviews or think-aloud protocols.

Web survey paradata is a rapidly developing field, and the mouse chase continues in hopes of correlating cursor moves with specific cognitive, affective, and motivational states of participants. 


\section{References}

Adair, C. (2014). Interventions for addressing faking on personality assessments for employee selection: A meta-analysis. College of Science and Health Theses and Dissertations. Paper 93.

Brenner, E., \& Smeets, J. B. (2003). Fast corrections of movements with a computer mouse. Spatial Vision, 16(3), 365-376.

Burns, G. N., Filipkowski, J. N., Morris, M. B., \& Shoda, E. A. (2015). Impact of electronic warnings on online personality scores and test-taker reactions in an applicant simulation. Computers in Human Behavior, 48, 163-172.

Clark, J. W., \& Stephane, A. L. (2018). Affordable Eye Tracking for Informed Web Design. In A. Marcus \& W. Wang (Eds.), Design, User Experience, and Usability: Theory and Practice (pp. 346-355). Springer International Publishing.

Curran, P. G. (2016). Methods for the detection of carelessly invalid responses in survey data. Journal of Experimental Social Psychology, 66, 4-19.

Fernández-Fontelo, A., Kieslich, P. J., Henninger, F., Kreuter, F., \& Greven, S. (2022). Predicting Question Difficulty in Web Surveys: A Machine Learning Approach Based on Mouse Movement Features. Social Science Computer Review, 1-22, online first.

Gatti, D., Marelli, M., \& Rinaldi, L. (2021). Predicting hand movements with distributional semantics: Evidence from mouse-tracking. https://psyarxiv.com/aw9vb/

Horwitz, R., Brockhaus, S., Henninger, F., Kieslich, P. J., Schierholz, M., Keusch, F., \& Kreuter, F. (2020). Learning from mouse movements: Improving questionnaires and 
respondents' user experience through passive data collection. In: P. Beatty, D. Collins, L. Kaye, J. L. Padilla, G. Willis, \& A. Wilmot (Eds.). Advances in Questionnaire Design, Development, Evaluation and Testing, 403-425. John Wiley \& Sons.

Horwitz, R., Kreuter, F., \& Conrad, F. (2017). Using mouse movements to predict web survey response difficulty. Social Science Computer Review, 35(3), 388-405.

Huang, J. L., Curran, P. G., Keeney, J., Poposki, E. M., \& DeShon, R. P. (2012). Detecting and deterring insufficient effort responding to surveys. Journal of Business and Psychology, 27(1), 99-114.

Huang, J., White, R. W., \& Dumais, S. (2011). No clicks, no problem: Using cursor movements to understand and improve search. Proceedings of the SIGCHI Conference on Human Factors in Computing Systems, 1225-1234.

Johnson, J. A. (2005). Ascertaining the validity of individual protocols from web-based personality inventories. Journal of Research in Personality, 39(1), 103-129.

Kieslich, P. J., \& Henninger, F. (2017). Mousetrap: An integrated, open-source mouse-tracking package. Behavior Research Methods, 49(5), 1652-1667.

Kirsh, I., \& Joy, M. (2020). Exploring Pointer Assisted Reading (PAR): Using Mouse Movements to Analyze Web Users' Reading Behaviors and Patterns. In C. Stephanidis, M. Kurosu, H. Degen, \& L. Reinerman-Jones (Eds.), HCI International 2020_Late Breaking Papers: Multimodality and Intelligence (pp. 156-173). Springer International Publishing.

Kroehne, U., \& Goldhammer, F. (2018). How to conceptualize, represent, and analyze log data from technology-based assessments? A generic framework and an application to 
questionnaire items. Behaviormetrika, 45(2), 527-563.

Malanchini, M., Rimfeld, K., Gidziela, A., Cheesman, R., Allegrini, A. G., Shakeshaft, N., Schofield, K., Packer, A., Ogden, R., McMillan, A., Ritchie, S. J., Dale, P. S., Eley, T. C., von Stumm, S., \& Plomin, R. (2021). Pathfinder: A gamified measure to integrate general cognitive ability into the biological, medical, and behavioural sciences. Molecular Psychiatry. https://doi.org/10.1038/s41380-021-01300-0

Meade, A. W., \& Craig, S. B. (2012). Identifying careless responses in survey data. Psychological Methods, 17(3), 437-455.

Rodden, K., Fu, X., Aula, A., \& Spiro, I. (2008). Eye-mouse coordination patterns on web search results pages. In CHI'08 extended abstracts on Human factors in computing systems (pp. 2997-3002).

Stieger, S., \& Reips, U.-D. (2010). What are participants doing while filling in an online questionnaire: A paradata collection tool and an empirical study. Computers in Human Behavior, 26(6), 1488-1495.

Stillman, P. E., Shen, X., \& Ferguson, M. J. (2018). How mouse-tracking can advance social cognitive theory. Trends in Cognitive Sciences, 22(6), 531-543.

Ulitzsch, E., Pohl, S., Khorramdel, L., Kroehne, U., \& von Davier, M. (2022). A response-timebased latent response mixture model for identifying and modeling careless and insufficient effort responding in survey data. Psychometrika, 87(2), 593-619.

Yamauchi, T., \& Xiao, K. (2018). Reading emotion from mouse cursor motions: Affective computing approach. Cognitive Science, 42(3), 771-819.

Zwarun, L., \& Hall, A. (2014). What's going on? Age, distraction, and multitasking during online survey taking. Computers in Human Behavior, 41, 236-244. 
https://doi.org/10.1016/j.chb.2014.09.041

Endnotes

${ }^{1}$ The number of $81 \%$ of respondents using mice as opposed to other devices (touchscreen, touchpad, etc.) was obtained in an additional survey conducted on a sample of more than 1000 participants of the panel used to recruit our sample using the same recruitment procedures and quotas. This number is in accord with other web-based studies (Fernandez-Fontelo et al., 2022). 


\title{
Mouse Chase: Detecting Careless and Unmotivated Responders Using Cursor Movements in Web-Based Surveys (Supplementary Online Materials)
}

\author{
Artur Pokropek, Tomasz Żółtak, Marek Muszyński,
}

Institute of Philosophy and Sociology, Polish Academy of Sciences

Contents

\author{
Experimental procedure $\quad \underline{2}$

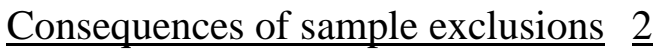 \\ $\underline{\text { Manipulation check }} \underline{3}$
}

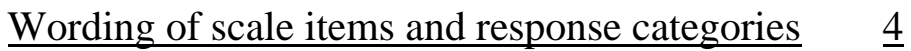

Supplementary results 7

$\underline{\text { Additional figures }} \quad \underline{10}$

$\underline{\text { Reanalysis using views on vaccines scale }} \underline{11}$ 


\section{Experimental procedure}

Table S1 Schematic outlook of experimental procedure

\begin{tabular}{|c|c|c|c|c|}
\hline $\begin{array}{l}\text { Ordinal } \\
\text { number }\end{array}$ & Measurement & Screens & $\begin{array}{c}\text { Response scale } \\
\text { length/format manipulation } \\
\end{array}$ & $\begin{array}{c}\text { Median } \\
\text { Time }\end{array}$ \\
\hline 1. & $\begin{array}{l}\text { Movies with instruction } \\
\text { manipulation }\end{array}$ & 1 & No & 2 minutes \\
\hline 2. & $\begin{array}{l}\text { Cognitive abilities test } \\
\text { Pathfinder }\end{array}$ & Many & No & 15 minutes \\
\hline 3. & Survey: vaccinations & 2 & Yes & \multirow{8}{*}{15 minutes } \\
\hline 4. & \begin{tabular}{|l|} 
Survey: general trust (source: \\
ESS)
\end{tabular} & 3 & Yes & \\
\hline 5. & $\begin{array}{l}\text { Survey: institutional trust } \\
\text { (adapted from ESS) }\end{array}$ & 2 & Yes & \\
\hline 6. & $\begin{array}{l}\text { Survey: reading attitudes } \\
\text { (source: PISA) }\end{array}$ & 1 & Yes & \\
\hline 7. & $\begin{array}{l}\text { Survey: reading materials } \\
\text { (source: PISA) }\end{array}$ & 2 & Yes & \\
\hline 8. & Manipulation check & 1 & No & \\
\hline 9. & $\begin{array}{l}\text { Self-reported survey diligence } \\
\text { and comments }\end{array}$ & 4 & No & \\
\hline 10. & Debriefing & 1 & No & \\
\hline
\end{tabular}

Note: ESS: European Social Survey; PISA: Programme for International Student Assessment

\section{Consequences of sample exclusions}

The experiment was begun by 3407 respondents. However, many of them had to be excluded from the analysis because they did not reach the analyzed scale while answering the survey (540 respondents), encountered technical difficulties while watching the video on the test instructions (202 respondents), spent more than 2 minutes answering the scale, a span that exceeded the maximum time for log-data collection' (118 respondents), had an Internet browser window that was too small for filling in the survey ${ }^{2}$ (30 respondents), left the survey browser window while answering the scale ( 25 respondents), or had broken records in their log-data regarding answering the scale (274 respondents), or did not pass a manipulation check (195 respondents; see section below). Eventually, 2023 respondents were included in the analysis.

'The amount of cursor moves data grows very fast with time and at some point it may become so large that its sheer size (in MBs) causes difficulties to process it and to send it over the Internet. These technical difficulties may cause lags in the survey interface and slow down respondent's web browser and computer. To diminish the probability of encountering such problems, on the basis of our previous experience, we decided to limit the period of process data collection to 2 minutes. Please also mind that exceeding this limit for a screen with only 11 survey 
items means that probably respondents are engaged in off-screen multitasking or have made a pause in the survey anyway.

${ }^{2}$ Survey questions in our questionnaire were presented in a tabular form with response categories put in columns and the items in rows. However, the survey platform we used had a socalled responsive layout - if the table did not fit in a browser window layout has changed with items being offered in a form of list instead of table.

Table S2 Number of respondents included into the final sample for each combination of experimental conditions

\begin{tabular}{lrrrr}
\hline & \multicolumn{3}{c}{ Instruction } & \\
\cline { 2 - 5 } Response scale & Standard Warning & Appeal & Total \\
\hline 4 cat. (all labelled) & 97 & 90 & 85 & 272 \\
5 cat. (all labelled) & 97 & 81 & 102 & 280 \\
6 cat. (all labelled) & 100 & 71 & 96 & 267 \\
7 cat. (all labelled) & 94 & 87 & 77 & 258 \\
10 cat. all labelled & 103 & 70 & 89 & 262 \\
10 cat. end labelled & 86 & 75 & 78 & 239 \\
11 cat. all labelled & 87 & 59 & 79 & 225 \\
11 cat. end labelled & 90 & 59 & 71 & 220 \\
\hline Total & 754 & 592 & 677 & 2023 \\
\hline
\end{tabular}

\section{Manipulation check}

Procedure: close to the end of the survey respondents were asked a set of 5 questions about whether the video they watched at the beginning of the survey contained specific information:

1. Warning that researchers are capable of detecting careless and dishonest respondents (true for warning instruction),

2. Warning that careless and dishonest respondents may lose their pay for the survey (true for warning instruction),

3. Summary of the survey content (see below),

4. Call for respondents' commitment, carefulness and honesty (true for both warning and appeal instructions),

5. Emphasis on the role of honesty and respondents' involvement in the development of science (true for appeal instruction).

The third item was supposed to be considered true for the appeal instruction because it was the only one including some more detailed information regarding survey content. However, respondents tended to choose this item irrespective of the instruction they were given. Because of this we decided to exclude this item from use in the manipulation check procedure. Respondents were assumed to pass the manipulation check (MC) if:

- Were given the standard instruction - irrespective of responses to the aforementioned items. 
- Agreed or strongly agreed to all the items relevant to the instruction he/she was given (i.e., items 1, 2 and 4 in the case of warning instruction or items 4 and 5 in the case of appeal instruction).

Number and percentage of respondents who passed the manipulation check for each instruction is presented in a table below (including only respondents that were not excluded from the analysis because of the technical reasons that were described in the paper).

Table S3 Number of respondents passing manipulation check

\begin{tabular}{ccrc}
\hline Instruction & \multicolumn{2}{c}{$\mathbf{N}$} & \multicolumn{1}{c}{ Pct. } \\
\cline { 2 - 4 } & Passed MC Failed MC & Passed MC \\
\hline Standard & 754 & 0 & $100.0 \%$ \\
Warning & 592 & 141 & $80.8 \%$ \\
Appeal & 677 & 54 & $92.6 \%$ \\
\hline Overall & 2023 & 195 & $90.4 \%$ \\
\hline
\end{tabular}

\section{Wording of scale items and response categories}

Table S4 Wording and ascription to dimensions of the PISA reading attitudes scale items

\begin{tabular}{lc}
\hline No. Item & Wording \\
\hline 1 I read only if I have to & - \\
2 Reading is one of my favourite hobbies & + \\
3 I like talking about books with other people & + \\
4 I find it hard to finish books & - \\
5 I feel happy if I receive a book as a present & + \\
6 For me, reading is a waste of time & + \\
7 I enjoy going to a bookstore or a library & - \\
8 I read only to get information that I need & - \\
9 I cannot sit still and read for more than a few minutes & + \\
10 I like to express my opinions about books I have read & + \\
11 I like to exchange books with my friends & + \\
\hline
\end{tabular}

Note: In the survey Polish translation as in PISA 2009 was used.

Table S5 Wording of the self-reported diligence scale. English (EN) and Polish (PL) versions

No.

Item

1ENI carefully read every survey item.

2ENI probably should have been more careful during this survey.

3ENI worked to the best of my abilities in this study.

4ENI put forth my best effort in responding to this survey.

5ENI didn't give this survey the time it deserved. 
\begin{tabular}{l}
\hline No. \\
\hline 6ENI was dishonest on some items. \\
7ENI was actively involved in this study. \\
8ENI rushed through this survey. \\
9ENI was easily distracted when answering the questions. \\
1PLUważnie przeczytałem/przeczytałam każde pytanie w tej ankiecie. \\
2PLPrawdopodobnie powinienem/powinnam w tej ankiecie odpowiadać uważniej. \\
3PLOdpowiadałem/odpowiadałam najlepiej, jak umiałem. \\
4PLStarałem/starałam się odpowiadając na pytania w tej ankiecie. \\
5PLNie poświęciłem/poświęciłam tej ankiecie tyle czasu, ile powinienem. \\
6PLByłem/byłam nieszczery w niektórych odpowiedziach. \\
7PLByłem/byłam aktywnie zaangażowany uczestnicząc w tej ankiecie. \\
8PLZrobiłem/zrobiłam tę ankietę w pośpiechu. \\
9PLŁatwo się rozpraszałem/rozpraszałam odpowiadając na pytania w tej ankiecie.
\end{tabular}

Note: In the survey Polish translation was used (items 1PL-9PL from the table above).

Table S6 Wording of response scale categories for different response scale lengths and formats used in the experiment (English translation in parenthesis)

\begin{tabular}{|c|c|c|c|}
\hline 4 cat. (all labelled) & 5 cat. (all labelled) & 6 cat. (all labelled) & 7 cat. (all labelled) \\
\hline $\begin{array}{l}\text { Zdecydowanie się } \\
\text { NIE zgadzam } \\
\text { (Strongly disagree) }\end{array}$ & $\begin{array}{l}\text { Zdecydowanie się NIE } \\
\text { zgadzam } \\
\text { (Strongly disagree) }\end{array}$ & $\begin{array}{l}\text { Zdecydowanie się NIE } \\
\text { zgadzam } \\
\text { (Strongly disagree) }\end{array}$ & $\begin{array}{l}\text { Zdecydowanie się NIE } \\
\text { zgadzam } \\
\text { (Strongly disagree) }\end{array}$ \\
\hline $\begin{array}{l}\text { NIE zgadzam się } \\
(\text { Disagree })\end{array}$ & $\begin{array}{l}\text { NIE zgadzam się } \\
\text { (Disagree) }\end{array}$ & $\begin{array}{l}\text { NIE zgadzam się } \\
(\text { Disagree })\end{array}$ & $\begin{array}{l}\text { NIE zgadzam się } \\
\text { (Disagree) }\end{array}$ \\
\hline $\begin{array}{l}\text { Zgadzam się } \\
\text { (Agree) }\end{array}$ & $\begin{array}{l}\text { Ani się nie zgadzam, } \\
\text { ani się zgadzam } \\
\text { (Neither disagree nor } \\
\text { agree) }\end{array}$ & $\begin{array}{l}\text { Raczej się NIE } \\
\text { zgadzam } \\
\text { (Rather disagree) }\end{array}$ & $\begin{array}{l}\text { Raczej się NIE } \\
\text { zgadzam } \\
\text { (Rather disagree) }\end{array}$ \\
\hline \multirow[t]{4}{*}{$\begin{array}{l}\text { Zdecydowanie się } \\
\text { zgadzam } \\
(\text { Strongly agree })\end{array}$} & $\begin{array}{l}\text { Zgadzam się } \\
\text { (Agree) }\end{array}$ & $\begin{array}{l}\text { Raczej się zgadzam } \\
\text { (Rather agree })\end{array}$ & $\begin{array}{l}\text { Ani się nie zgadzam, } \\
\text { ani się zgadzam } \\
\text { (Neither disagree nor } \\
\text { agree) }\end{array}$ \\
\hline & $\begin{array}{l}\text { Zdecydowanie się } \\
\text { zgadzam } \\
\text { (Strongly agree) }\end{array}$ & $\begin{array}{l}\text { Zgadzam się } \\
\text { (Agree) }\end{array}$ & $\begin{array}{l}\text { Raczej się zgadzam } \\
\text { (Rather agree) }\end{array}$ \\
\hline & & $\begin{array}{l}\text { Zdecydowanie się } \\
\text { zgadzam } \\
(\text { Strongly agree })\end{array}$ & $\begin{array}{l}\text { Zgadzam się } \\
\text { (Agree) }\end{array}$ \\
\hline & & & $\begin{array}{l}\text { Zdecydowanie się } \\
\text { zgadzam }\end{array}$ \\
\hline
\end{tabular}




\begin{tabular}{|c|c|c|c|}
\hline & & & (Strongly agree) \\
\hline 10 cat. all labelled & 10 cat. end labelled & 11 cat. all labelled & 11 cat. end labelled \\
\hline $\begin{array}{l}\text { Całkowicie się NIE } \\
\text { zgadzam } \\
\text { (Entirely disagree) }\end{array}$ & $\begin{array}{l}\text { Całkowicie się NIE } \\
\text { zgadzam } \\
\text { (Entirely disagree) }\end{array}$ & $\begin{array}{l}\text { Całkowicie się NIE } \\
\text { zgadzam } \\
\text { (Entirely disagree) }\end{array}$ & $\begin{array}{l}\text { Całkowicie się NIE } \\
\text { zgadzam } \\
\text { (Entirely disagree) }\end{array}$ \\
\hline $\begin{array}{l}\text { Zdecydowanie się } \\
\text { NIE zgadzam } \\
\text { (Strongly disagree) }\end{array}$ & 1 & $\begin{array}{l}\text { Zdecydowanie się NIE } \\
\text { zgadzam } \\
\text { (Strongly disagree) }\end{array}$ & 1 \\
\hline $\begin{array}{l}\text { NIE zgadzam się } \\
(\text { Disagree })\end{array}$ & 2 & $\begin{array}{l}\text { NIE zgadzam się } \\
(\text { Disagree })\end{array}$ & 2 \\
\hline $\begin{array}{l}\text { W większości się } \\
\text { NIE zgadzam } \\
\text { (Mostly disagree) }\end{array}$ & 3 & $\begin{array}{l}\text { W większości się NIE } \\
\text { zgadzam } \\
(\text { Mostly disagree })\end{array}$ & 3 \\
\hline $\begin{array}{l}\text { Raczej się NIE } \\
\text { zgadzam } \\
\text { (Rather disagree) }\end{array}$ & 4 & $\begin{array}{l}\text { Raczej się NIE } \\
\text { zgadzam } \\
(\text { Rather disagree) }\end{array}$ & 4 \\
\hline $\begin{array}{l}\text { Raczej się zgadzam } \\
\text { (Rather agree) }\end{array}$ & 5 & $\begin{array}{l}\text { Ani się nie zgadzam, } \\
\text { ani się zgadzam } \\
\text { (Neither disagree nor } \\
\text { agree) }\end{array}$ & 5 \\
\hline $\begin{array}{l}\text { W większości się } \\
\text { zgadzam } \\
(\text { Mostly agree })\end{array}$ & 6 & $\begin{array}{l}\text { Raczej się zgadzam } \\
\text { (Rather agree) }\end{array}$ & 6 \\
\hline $\begin{array}{l}\text { Zgadzam się } \\
\text { (Agree) }\end{array}$ & 7 & $\begin{array}{l}\text { W większości się } \\
\text { zgadzam } \\
(\text { Mostly agree })\end{array}$ & 7 \\
\hline $\begin{array}{l}\text { Zdecydowanie się } \\
\text { zgadzam } \\
(\text { Strongly agree })\end{array}$ & 8 & $\begin{array}{l}\text { Zgadzam się } \\
\text { (Agree) }\end{array}$ & 8 \\
\hline \multirow[t]{2}{*}{$\begin{array}{l}\text { Całkowicie się } \\
\text { zgadzam } \\
(\text { Entirely agree) }\end{array}$} & $\begin{array}{l}\text { Całkowicie się } \\
\text { zgadzam } \\
\text { (Entirely agree) }\end{array}$ & $\begin{array}{l}\text { Zdecydowanie się } \\
\text { zgadzam } \\
(\text { Strongly agree })\end{array}$ & 9 \\
\hline & & $\begin{array}{l}\text { Całkowicie się } \\
\text { zgadzam } \\
(\text { Entirely agree })\end{array}$ & $\begin{array}{l}\text { Całkowicie się } \\
\text { zgadzam } \\
\text { (Entirely agree) }\end{array}$ \\
\hline
\end{tabular}

Note: In the survey Polish wording was used. 


\section{Supplementary results}

Table S7 Pearson correlations between CMIs.

\begin{tabular}{|c|c|c|c|c|c|}
\hline & \multicolumn{5}{|c|}{$\log (d X$ X_rel $) \log (d Y$ Yrel $)$ sqrt(flipX) sqrt(flipY) $\log (a X) \log (a Y) \log (v X)$} \\
\hline $\log \left(d Y \_r e l\right)$ & $0.51 * * *$ & & & & \\
\hline $\operatorname{sqrt}(f l i p X)$ & $0.55 * * *$ & $0.54 * * *$ & & & \\
\hline sqrt(flipY) & $0.68 * * *$ & $0.62 * * *$ & $0.82 * * *$ & & \\
\hline $\log (\mathbf{a X})$ & $0.53 * * *$ & $0.32 * * *$ & $0.19 * * *$ & $0.34 * * *$ & \\
\hline $\log (\mathbf{a Y})$ & $-0.07 * *$ & $0.31 * * *$ & -0.00 & $0.06^{*}$ & $0.72 * * *$ \\
\hline $\log (\mathbf{v X})$ & $0.60 * * *$ & $0.21 * * *$ & $0.15 * * *$ & $0.26 * * *$ & $0.84 * * * 0.47 * * *$ \\
\hline $\log (\mathbf{v Y})$ & $-0.28 * * *$ & $0.22 * * *$ & $-0.20 * * *$ & $-0.21 * * *$ & $0.41 * * * 0.77 * * * 0.45 * * *$ \\
\hline
\end{tabular}

Table S8 Pearson correlations between C/IER indices.

\begin{tabular}{ccccc}
\hline \multicolumn{5}{c}{ Longstring Mahalanobis Pathfinder QC failures Self-reported diligence } \\
\hline Mahalanobis & $-0.13 * * *$ & & & \\
Pathfinder QC failures & $0.24 * * *$ & 0.02 & $-0.29 * * *$ & \\
Self-reported diligence & $-0.41 * * *$ & $0.09 * * *$ & $-0.18 * * *$ & $0.34 * * *$ \\
\hline $\log ($ Page time) & $-0.42 * * *$ & $0.13 * * *$ & \\
\hline
\end{tabular}

$\mathrm{N}=2007$ for correlations involving self-reported diligence

$\mathrm{N}=2023$ for all the other correlation

$* * * \mathrm{p}<0.001 ; * * \mathrm{p}<0.01 ; * \mathrm{p}<0.05$

Table S9 Ranges (min; max) of Pearson correlations between cursor moves and CIE/R indices across different response scales and formats

\begin{tabular}{lccccc}
\hline Measure & Longstring & Mahalanobis & $\begin{array}{l}\text { Pathfinder QC } \\
\text { Failures }\end{array}$ & $\begin{array}{l}\text { Self-Reported } \\
\text { Diligence }\end{array}$ & $\begin{array}{l}\text { log(Page } \\
\text { Time })\end{array}$ \\
\hline $\log \left(\mathrm{dX} \_\right.$rel $)$ & $\begin{array}{c}(-0.728 ;- \\
0.572)\end{array}$ & $(0.091 ; 0.279)$ & $(-0.467 ;-0.130)$ & $(0.386 ; 0.575)$ & $(0.464 ; 0.662)$ \\
& & & & \\
$\log \left(\mathrm{dY} \_\right.$rel $)$ & $(-0.296 ;-$ & $(0.014 ; 0.157)$ & $(-0.118 ; 0.042)$ & $(0.061 ; 0.285)$ & $(0.343 ; 0.451)$ \\
& $0.094)$ & & & & \\
sqrt(flipsX) & $(-0.440 ;-$ & $(0.018 ; 0.208)$ & $(-0.282 ; 0.016)$ & $(0.139 ; 0.279)$ & $(0.455 ; 0.534)$ \\
& $0.140)$ & & & & \\
sqrt(flipsY) & $(-0.608 ;-$ & $(0.032 ; 0.172)$ & $(-0.311 ;-0.020)$ & $(0.237 ; 0.358)$ & $(0.473 ; 0.557)$ \\
& $0.353)$ & & & & $(0.062 ; 0.314)$ \\
$\log (\mathrm{vX})$ & $(-0.498 ;-$ & $(-0.038 ;$ & $(-0.255 ;-0.033)$ & $(-0.406 ;-$ \\
& $0.245)$ & $0.226)$ & & $(-0.385 ;-0.140)$ & $(-0.798 ;-$ \\
$\log (\mathrm{vY})$ & $(0.321 ; 0.451)$ & $(-0.248 ;$ & $(0.001 ; 0.340)$ & & $0.708)$
\end{tabular}




\begin{tabular}{lccccc}
$\log (\mathrm{aX})$ & $(-0.379 ;-$ & $(-0.024 ;$ & $(-0.172 ;-0.070)$ & $(0.070 ; 0.258)$ & $(-0.353 ;-$ \\
& $0.157)$ & $0.157)$ & & & $0.083)$ \\
$\log (\mathrm{aY})$ & $(0.120 ; 0.321)$ & $(-0.185 ;$ & $(-0.002 ; 0.207)$ & $(-0.249 ;-0.109)$ & $(-0.635 ;-$ \\
& & $0.052)$ & & & $0.486)$ \\
\hline
\end{tabular}

$\mathrm{N}$ for different response scale lengths and formats ranges from 220 to 280

Table S10 Effect size of instruction type in models predicting values of specific CMIs and CIE/R indices using type of test instructions and response scale length and format

\begin{tabular}{lcccc}
\hline & \multicolumn{2}{l}{ Warning instruction effect } & \multicolumn{2}{l}{ Appeal instruction effect } \\
\cline { 2 - 5 } Measure & Cohen's $d$ & $p$ (Wald's test) & Cohen's $a$ & $p$ (Wald's test) \\
\hline $\log (\mathrm{dX}$ _rel) & 0.15 & 0.006 & 0.16 & 0.003 \\
$\log (\mathrm{dY}$ rel) & 0.01 & 0.866 & 0.10 & 0.068 \\
sqrt(flipsX) & 0.07 & 0.188 & 0.09 & 0.082 \\
sqrt(flipsY) & 0.09 & 0.119 & 0.13 & 0.015 \\
$\log (\mathrm{aX})$ & -0.03 & 0.577 & 0.05 & 0.395 \\
$\log (\mathrm{aY})$ & -0.19 & 0.000 & -0.08 & 0.152 \\
$\log (\mathrm{vX})$ & -0.02 & 0.733 & -0.01 & 0.824 \\
$\log (\mathrm{v} Y)$ & -0.21 & 0.000 & -0.19 & 0.000 \\
\hline Self-reported diligence & 0.42 & 0.000 & 0.30 & 0.000 \\
Longstring & -0.11 & 0.045 & -0.17 & 0.002 \\
$\log ($ Page time) & 0.20 & 0.000 & 0.19 & 0.000 \\
Pathfinder QC failures & -0.07 & 0.174 & -0.05 & 0.372 \\
Mahalanobis & -0.05 & 0.360 & -0.05 & 0.337 \\
\hline N & &
\end{tabular}

$\mathrm{N}=2007$ for analysis involving self-reported diligence as a dependent variable; $\mathrm{N}=2023$ for all the other analysis Table S11 Effect size of instruction type in models predicting values of specific CMIs and CIE/R indices using type of test instructions for specific response scale length and format - CMIs and $C I E R / R$ indices for which interaction effect of instruction type and response scale length and format was statistically significant

\begin{tabular}{|c|c|c|c|c|c|c|c|c|c|}
\hline \multirow[b]{2}{*}{ Measure } & \multirow[b]{2}{*}{$\begin{array}{l}\text { Response } \\
\text { scale }\end{array}$} & \multirow[b]{2}{*}{$\mathrm{N}$} & \multirow[b]{2}{*}{$\eta^{2}$} & \multirow[b]{2}{*}{$\mathrm{F}$} & \multirow[b]{2}{*}{$\mathrm{p}$} & \multicolumn{2}{|c|}{$\begin{array}{c}\text { Warning instruction } \\
\text { effect }\end{array}$} & \multicolumn{2}{|c|}{$\begin{array}{c}\text { Appeal instruction } \\
\text { effect }\end{array}$} \\
\hline & & & & & & Cohen's c & $\begin{array}{c}p \text { (Wald's } \\
\text { test) }\end{array}$ & Cohen's c & $\begin{array}{c}p(\text { Wald's } \\
\text { test })\end{array}$ \\
\hline \multirow[t]{2}{*}{ dY_rel } & $\begin{array}{l}4 \text { cat. (all } \\
\text { labelled) }\end{array}$ & 272 & 0.017 & 2.26 & 0.106 & 0.15 & 0.294 & 0.32 & 0.035 \\
\hline & $\begin{array}{l}5 \text { cat. (all } \\
\text { labelled) }\end{array}$ & 280 & 0.008 & 1.07 & 0.344 & 0.21 & 0.172 & 0.16 & 0.267 \\
\hline
\end{tabular}




\begin{tabular}{|c|c|c|c|c|c|c|c|c|c|}
\hline & $\begin{array}{l}6 \text { cat. (all } \\
\text { labelled) }\end{array}$ & 267 & 0.052 & 7.31 & 0.001 & -0.53 & 0.001 & 0.01 & 0.973 \\
\hline & $\begin{array}{l}7 \text { cat. (all } \\
\text { labelled) }\end{array}$ & 258 & 0.014 & 1.83 & 0.163 & 0.29 & 0.057 & 0.14 & 0.352 \\
\hline & $\begin{array}{l}10 \text { cat. all } \\
\text { labelled }\end{array}$ & 262 & 0.003 & 0.42 & 0.656 & -0.13 & 0.391 & -0.01 & 0.938 \\
\hline & $\begin{array}{l}10 \text { cat. end } \\
\text { labelled }\end{array}$ & 239 & 0.007 & 0.83 & 0.437 & 0.05 & 0.739 & 0.20 & 0.211 \\
\hline & $\begin{array}{l}11 \text { cat. all } \\
\text { labelled }\end{array}$ & 225 & 0.004 & 0.47 & 0.627 & -0.13 & 0.454 & 0.03 & 0.826 \\
\hline & $\begin{array}{l}11 \text { cat. end } \\
\text { labelled }\end{array}$ & 220 & 0.005 & 0.51 & 0.600 & 0.11 & 0.512 & -0.07 & 0.670 \\
\hline \multirow[t]{8}{*}{$\begin{array}{l}\text { Pathfinder QC } \\
\text { failures }\end{array}$} & $\begin{array}{l}4 \text { cat. (all } \\
\text { labelled) }\end{array}$ & 272 & 0.029 & 4.06 & 0.018 & -0.40 & 0.007 & -0.08 & 0.574 \\
\hline & $\begin{array}{l}5 \text { cat. (all } \\
\text { labelled) }\end{array}$ & 280 & 0.011 & 1.56 & 0.211 & 0.03 & 0.830 & -0.20 & 0.153 \\
\hline & $\begin{array}{l}6 \text { cat. (all } \\
\text { labelled) }\end{array}$ & 267 & 0.033 & 4.45 & 0.013 & 0.36 & 0.021 & -0.09 & 0.532 \\
\hline & $\begin{array}{l}7 \text { cat. (all } \\
\text { labelled) }\end{array}$ & 258 & 0.003 & 0.37 & 0.691 & 0.01 & 0.962 & 0.12 & 0.434 \\
\hline & $\begin{array}{l}10 \text { cat. all } \\
\text { labelled }\end{array}$ & 262 & 0.004 & 0.50 & 0.609 & -0.00 & 0.979 & -0.13 & 0.364 \\
\hline & $\begin{array}{l}10 \text { cat. end } \\
\text { labelled }\end{array}$ & 239 & 0.008 & 0.93 & 0.394 & -0.13 & 0.415 & -0.21 & 0.178 \\
\hline & $\begin{array}{l}11 \text { cat. all } \\
\text { labelled }\end{array}$ & 225 & 0.017 & 1.87 & 0.157 & -0.12 & 0.463 & 0.20 & 0.201 \\
\hline & $\begin{array}{l}11 \text { cat. end } \\
\text { labelled }\end{array}$ & 220 & 0.037 & 4.19 & 0.016 & -0.36 & 0.032 & 0.14 & 0.391 \\
\hline
\end{tabular}




\section{Additional figures}

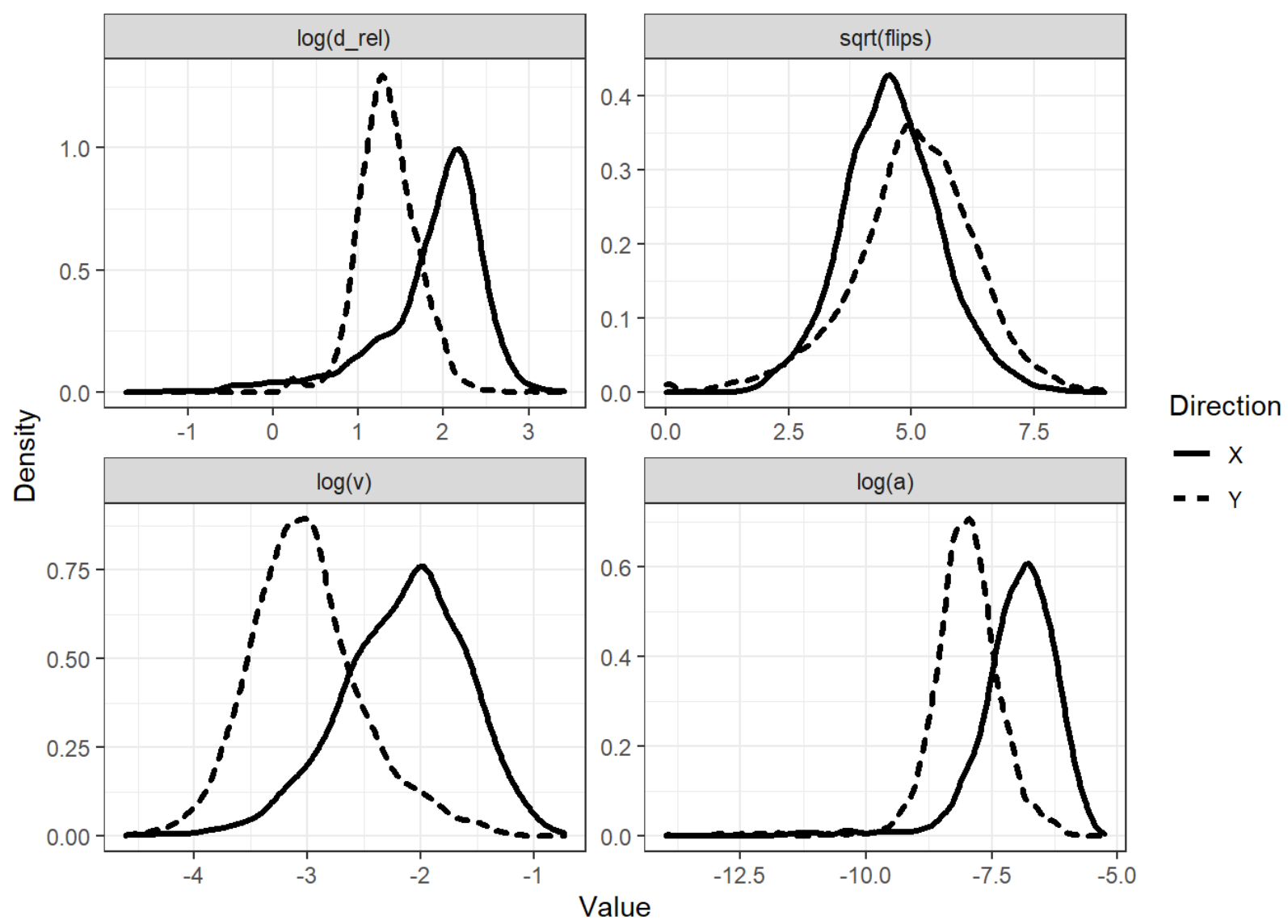

Figure S1 Distributions of mouse moves indices in the full sample. 

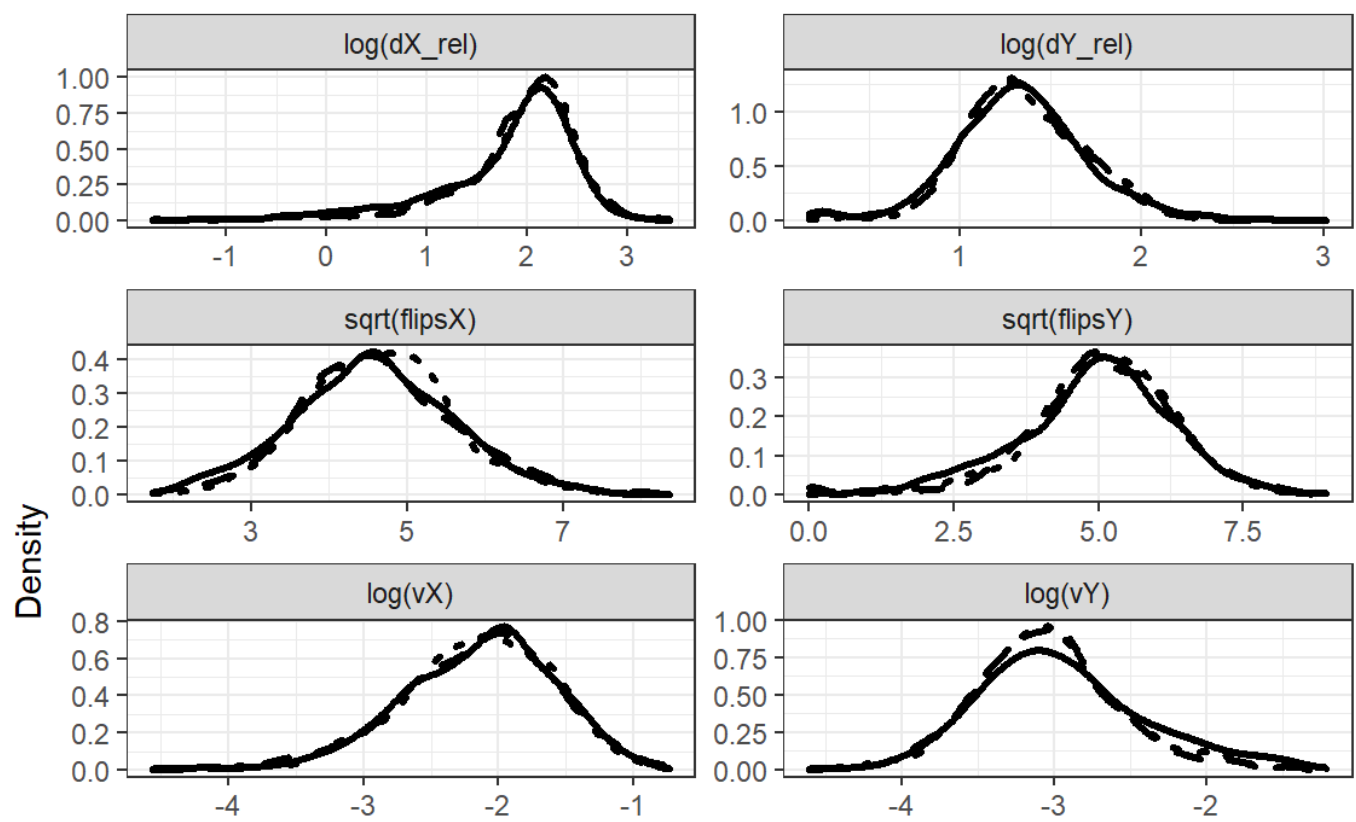

Instruction
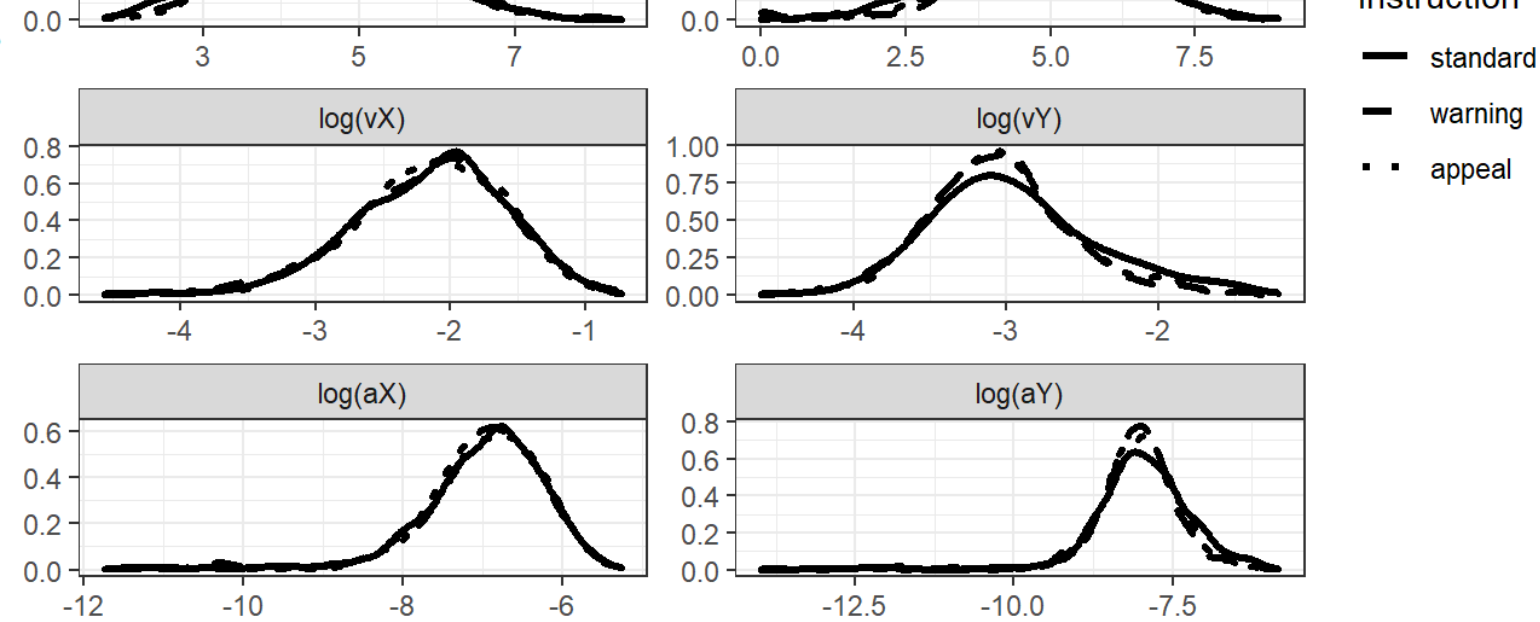

- appeal

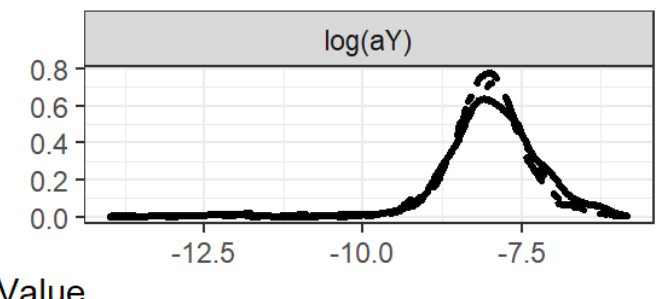

Figure S2 Distributions of mouse moves indices among respondents with a specific type of instruction. Only respondents who passed the manipulation check were included.

\section{Reanalysis using views on vaccines scale}

Table S12 Wording of the views on vaccines scale (English translations in parenthesis).

No. Item Wording

1 Ważne jest, aby każdy miał podstawowe szczepienia. (It is important that everyone has basic vaccinations.)

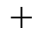

2 Szczepienia są ważne, ponieważ chronią nie tylko Pana/Panią, ale także inne osoby. (Vaccinations are important because they protect not only you but others as well.)

3 Niewykonanie szczepień może prowadzić do poważnych problemów zdrowotnych. (Not getting vaccinations can lead to serious health problems.)

4 Szczepienia są ważne tylko dla dzieci. (Vaccinations are only important for children.)

5 Szczepionki są poddawane rygorystycznym badaniom, zanim zostaną dopuszczone do stosowania.

(Vaccines are rigorously tested before they are approved for use.)

6 Szczepionki mogą wywoływać poważne choroby (np. bezpłodność, autyzm itp.).

(Vaccines can cause serious diseases (e.g. infertility, autism, etc.).) 


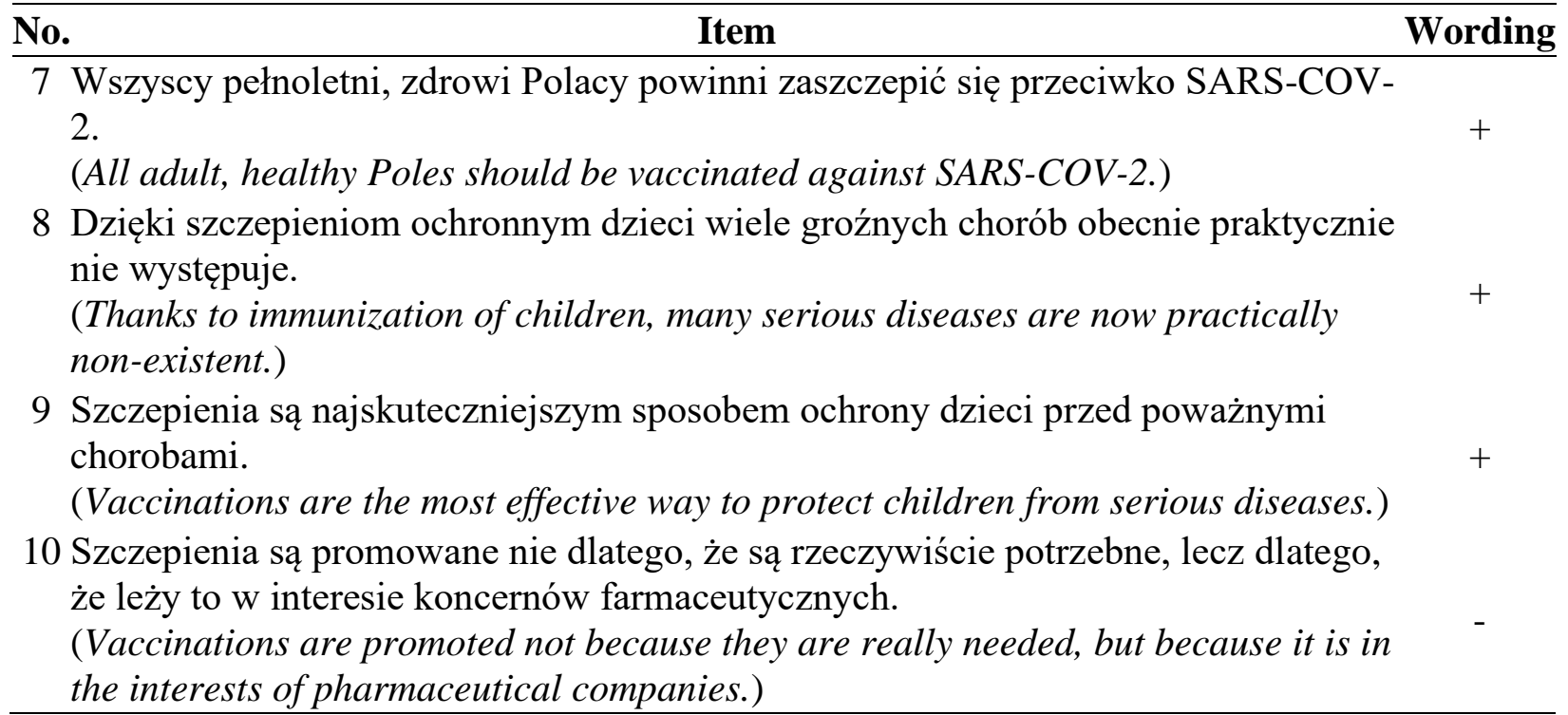

Note: In the survey Polish wording was used.

Table S13 Pearson correlations between CMIs.

$\log \left(d X \_r e l\right) \log \left(d Y \_r e l\right) s q r t(f l i p X) \operatorname{sqrt}(f l i p Y) \log (a X) \log (a Y) \log (v X)$

\begin{tabular}{|c|c|c|c|c|c|c|c|}
\hline $\log (\mathrm{dY} Y$ rel $)$ & $0.50 * * *$ & & & & & & \\
\hline sqrt(flipX) & $0.55 * * *$ & $0.56 * * *$ & & & & & \\
\hline sqrt(flipY) & $0.65 * * *$ & $0.61 * * *$ & $0.84 * * *$ & & & & \\
\hline $\log (\mathbf{a X})$ & $0.48 * * *$ & $0.29 * * *$ & $0.17 * * *$ & $0.27 * * *$ & & & \\
\hline $\log (a Y)$ & -0.02 & $0.35 * * *$ & 0.04 & $0.08 * *$ & $0.76 * * *$ & & \\
\hline $\log (v X)$ & $0.56 * * *$ & $0.23 * * *$ & $0.17 * * *$ & $0.22 * * *$ & $0.84 * * *$ & $0.57 * * *$ & \\
\hline $\log (v Y)$ & $-0.24 * * *$ & $0.31 * * *$ & $-0.10 * * *$ & $-0.14 * * *$ & $0.42 * * *$ & $0.79 * * *$ & $0.50 * * *$ \\
\hline
\end{tabular}

Table S14 Pearson correlations between C/IER indices.

Longstring Mahalanobis Pathfinder QC failures Self-reported diligence

\begin{tabular}{ccccc}
\hline Mahalanobis & $-0.18 * * *$ & & & \\
Pathfinder QC failures & $0.21 * * *$ & -0.01 & & \\
Self-reported diligence & $-0.37 * * *$ & $0.09 * * *$ & $-0.28 * * *$ & $0.34 * * *$ \\
\hline $\log ($ Page time) & $-0.49 * * *$ & $0.15 * * *$ & $-0.21 * * *$ & \\
\hline
\end{tabular}

$\mathrm{N}=1809$ for correlation involving self-reported diligence

$\mathrm{N}=1825$ for all the other correlations

*** $\mathrm{p}<0.001 ; * * \mathrm{p}<0.01 ; * \mathrm{p}<0.05$

Table S15 Pearson correlations between cursor moves and CIE/R indices across the whole dataset 


\begin{tabular}{|c|c|c|c|c|c|}
\hline Measure & Longstring & Mahalanobis & $\begin{array}{l}\text { Pathfinder QC } \\
\text { Failures }\end{array}$ & $\begin{array}{l}\text { Self-Reported } \\
\text { Diligence }\end{array}$ & $\begin{array}{l}\log (\text { Page } \\
\text { Time })\end{array}$ \\
\hline $\log (\mathrm{dX}$ _rel $)$ & $-0.58 * * *$ & $0.12 * * *$ & $-0.19 * * *$ & $0.34 * * *$ & $0.56 * * *$ \\
\hline $\log (\mathrm{dY}$ _rel $)$ & $-0.09 * * *$ & $0.14 * * *$ & -0.01 & $0.05 *$ & $0.33 * * *$ \\
\hline sqrt(flipsX) & $-0.25 * * *$ & $0.09 * * *$ & $-0.06^{*}$ & $0.12 * * *$ & $0.44 * * *$ \\
\hline sqrt(flipsY) & $-0.34 * * *$ & $0.08 * * *$ & $-0.10 * * *$ & $0.19 * * *$ & $0.49 * * *$ \\
\hline $\log (\mathrm{vX})$ & $-0.11 * * *$ & 0.01 & $-0.05^{*}$ & $0.08 * * *$ & $-0.37 * * *$ \\
\hline $\log (\mathrm{vY})$ & $0.46 * * *$ & $-0.07 * *$ & $0.16 * * *$ & $-0.27 * * *$ & $-0.74 * * *$ \\
\hline $\log (\mathrm{aX})$ & -0.02 & $-0.08 * * *$ & $-0.07 * *$ & 0.04 & $-0.34 * * *$ \\
\hline $\log (\mathrm{aY})$ & $0.35 * * *$ & $-0.14 * * *$ & $0.06 * *$ & $-0.19 * * *$ & $-0.62 * * *$ \\
\hline
\end{tabular}

$\mathrm{N}=1809$ for correlation involving self-reported diligence.

$\mathrm{N}=1825$ for all the other correlations.

$* * * p<.001 ; * * p<.01, * p<.05$.

Table S16 Results of ANOVAs (type II tests) predicting a given measure using type of survey instruction, response scale length and format, and interaction of the two

Instruction main effect Response scale main effec Interaction: instruction X response scale

\begin{tabular}{|c|c|c|c|c|c|c|c|c|c|}
\hline \multirow{2}{*}{ Measure } & & & & & & & & & \\
\hline & $F$ & $p$ & partial $\eta^{2}$ & $F$ & $p$ & partial $\eta^{2}$ & $F$ & $p$ & partial $\eta^{2}$ \\
\hline $\log (\mathrm{dX}$ _rel $)$ & 6.03 & 0.002 & 0.007 & 3.37 & 0.001 & 0.013 & 1.51 & 0.101 & 0.012 \\
\hline $\log \left(\mathrm{d} Y \_r e l\right)$ & 2.44 & 0.087 & 0.003 & 11.63 & 0.000 & 0.043 & 1.57 & 0.079 & 0.012 \\
\hline sqrt(flipsX) & 0.93 & 0.396 & 0.001 & 2.00 & 0.052 & 0.008 & 1.31 & 0.195 & 0.010 \\
\hline sqrt(flipsY) & 0.53 & 0.591 & 0.001 & 1.93 & 0.061 & 0.007 & 1.12 & 0.338 & 0.009 \\
\hline $\log (\mathrm{aX})$ & 2.90 & 0.055 & 0.003 & 1.97 & 0.056 & 0.008 & 0.87 & 0.595 & 0.007 \\
\hline $\log (\mathrm{aY})$ & 4.62 & 0.010 & 0.005 & 1.65 & 0.116 & 0.006 & 1.32 & 0.186 & 0.010 \\
\hline $\log (\mathrm{v} X)$ & 1.70 & 0.183 & 0.002 & 1.72 & 0.101 & 0.007 & 0.90 & 0.559 & 0.007 \\
\hline $\log (\mathrm{vY})$ & 5.30 & 0.005 & 0.006 & 1.65 & 0.116 & 0.006 & 1.25 & 0.231 & 0.010 \\
\hline $\begin{array}{l}\text { Self-reported } \\
\text { diligence }\end{array}$ & 24.02 & 0.000 & 0.026 & 1.37 & 0.216 & 0.005 & 1.19 & 0.280 & 0.009 \\
\hline Longstring & 1.68 & 0.186 & 0.002 & 1.33 & 0.233 & 0.005 & 1.54 & 0.088 & 0.012 \\
\hline $\log ($ Page time $)$ & 5.93 & 0.003 & 0.006 & 3.15 & 0.003 & 0.012 & 1.49 & 0.106 & 0.011 \\
\hline $\begin{array}{l}\text { Pathfinder QC } \\
\text { failures }\end{array}$ & 0.88 & 0.413 & 0.001 & 0.57 & 0.783 & 0.002 & 2.12 & 0.009 & 0.016 \\
\hline Mahalanobis & 1.01 & 0.366 & 0.001 & 120.09 & 0.000 & 0.317 & 0.93 & 0.522 & 0.007 \\
\hline
\end{tabular}


$\mathrm{N}=1809$ for analysis involving self-reported diligence as a dependent variable

$\mathrm{N}=1825$ for all the other analysis

Note: Test statistics and partial $\eta^{2}$ for main effects computed in the absence of the interaction effect (type II test).

Table S17 Effect size of instruction type in models predicting values of specific CMIs and CIE/R indices using type of test instructions and response scale length and format

Warning instruction effect Appeal instruction effect

\begin{tabular}{lcccc} 
& Cohen's $d$ & $p$ (Wald's test) & Cohen's $a$ & $p$ (Wald's test) \\
\cline { 2 - 5 } $\log (\mathrm{dX}$ _rel $)$ & 0.08 & 0.159 & 0.19 & 0.001 \\
$\log (\mathrm{dY}$ _rel $)$ & -0.03 & 0.622 & 0.09 & 0.089 \\
sqrt(flipsX) & 0.03 & 0.623 & 0.08 & 0.176 \\
sqrt(flipsY) & 0.02 & 0.740 & 0.06 & 0.310 \\
$\log (\mathrm{aX})$ & -0.07 & 0.233 & 0.07 & 0.183 \\
$\log (\mathrm{aY})$ & -0.18 & 0.002 & -0.07 & 0.233 \\
$\log (\mathrm{vX})$ & -0.06 & 0.320 & 0.05 & 0.348 \\
$\log (\mathrm{vY})$ & -0.18 & 0.002 & -0.13 & 0.017 \\
\hline Self-reported diligence & 0.38 & 0.000 & 0.28 & 0.000 \\
Longstring & -0.06 & 0.328 & -0.10 & 0.068 \\
$\log ($ Page time $)$ & 0.15 & 0.009 & 0.18 & 0.001 \\
Pathfinder QC failures & -0.07 & 0.256 & -0.06 & 0.259 \\
Mahalanobis & -0.05 & 0.379 & 0.03 & 0.549
\end{tabular}

$\mathrm{N}=1809$ for analysis involving self-reported diligence as a dependent variable $\mathrm{N}=1825$ for all the other analysis 


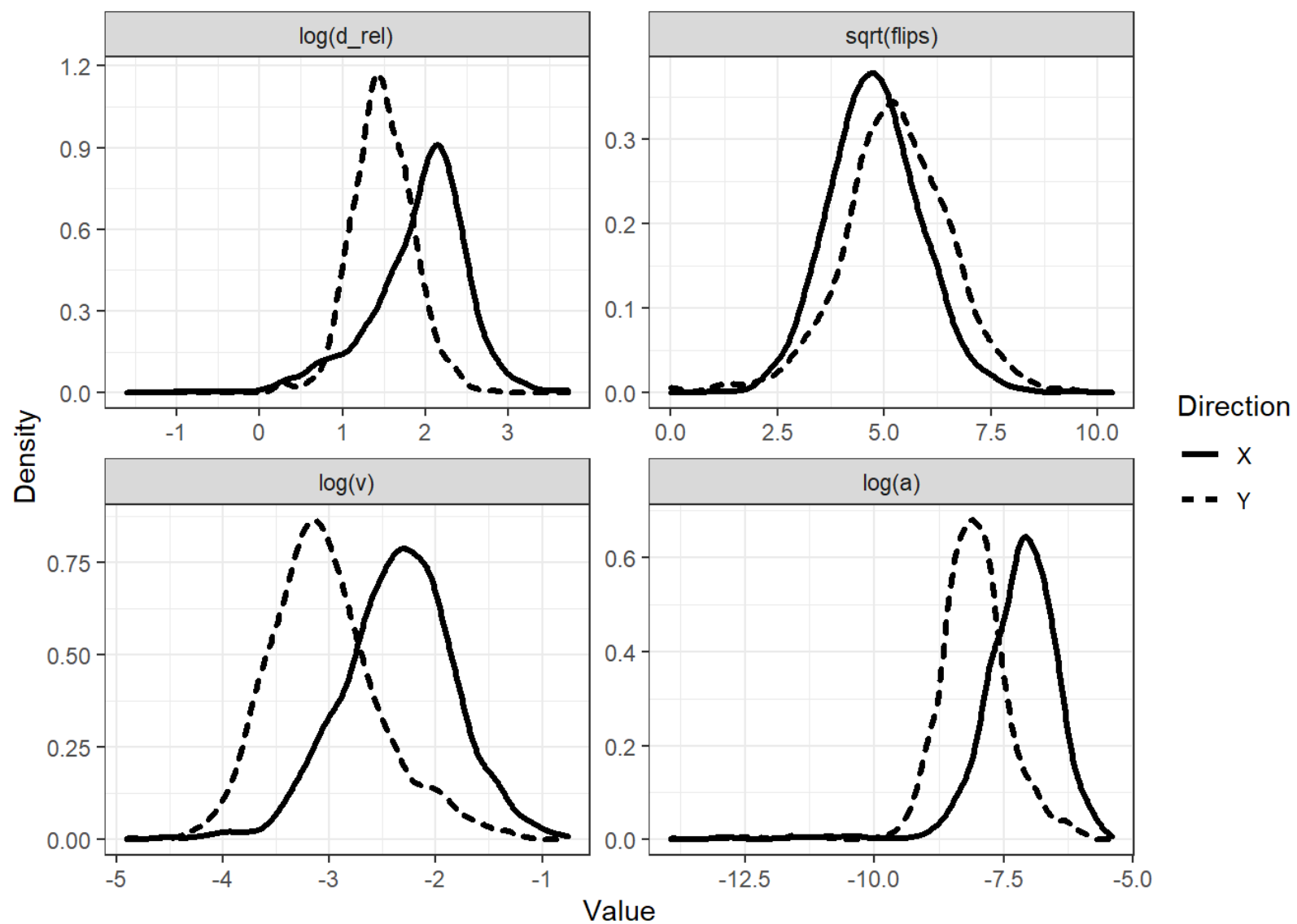

Figure S3 Distributions of mouse moves indices in the full sample-views on vaccines scale. 

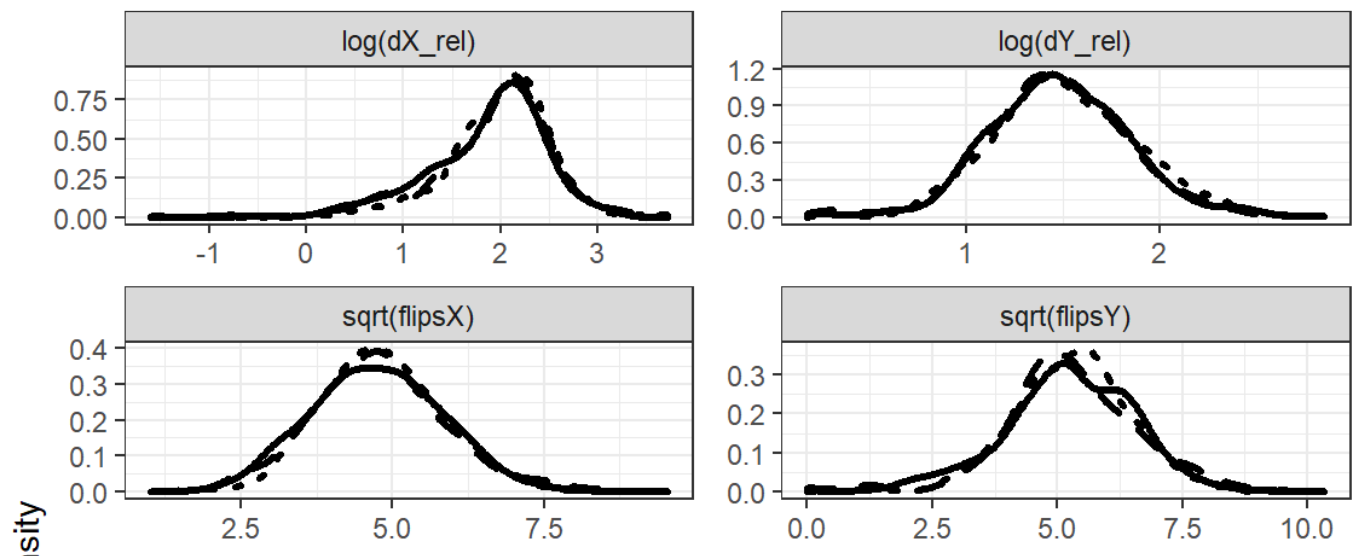

Instruction
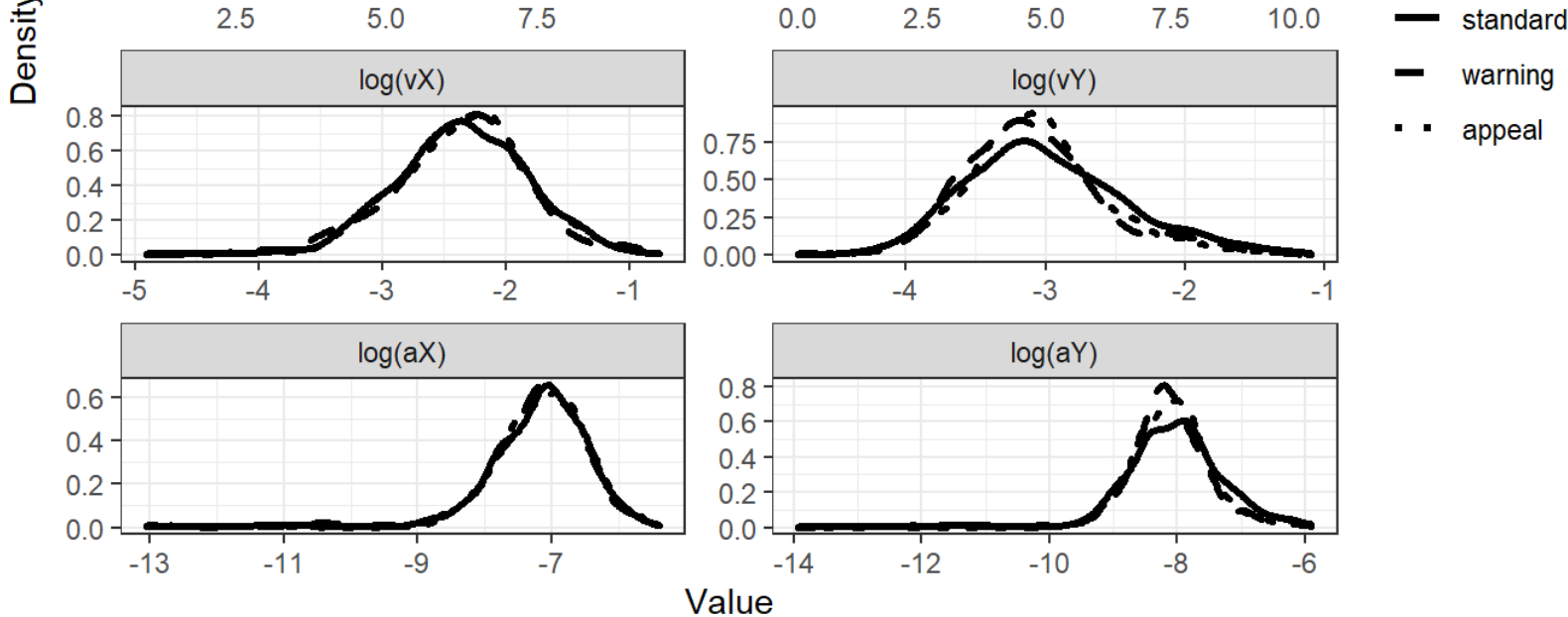

Figure S4 Distributions of mouse moves indices among respondents with a specific type of instruction. Only respondents who passed the manipulation check were included - views on vaccines scale. 